\title{
Moving Texts: A Hermeneutics of the Gospel According to Hollywood
}

\author{
Paul Clogher \\ Waterford Institute of Technology, Ireland
}

\begin{abstract}
The Hollywood Jesus epics re-visualize the gospel story against the anxious backdrops of secularization, cultural pluralism, and moral skepticism. While these epics are often derided for their lack of theological insight, cultural awareness, or aesthetic taste, this article argues for a re-appreciation of the genre's internal pluralism and hermeneutical significance. Focusing on Cecil B. DeMille's The King of Kings (1927) and Nicholas Ray's King of Kings (1961), it reflects on the epic as a tradition-forming moment in the Jesus story's reception. Both DeMille and Ray offer competing interpretations of Jesus, thus illustrating how the genre functions as a site of christological and hermeneutical reflection. Against this backdrop, I argue for a reinterpretation of the genre and, further, proffer a hermeneutical exploration of cinema more broadly as a central moment in the dialogue between Christianity and popular culture.
\end{abstract}

\section{Introduction}

Since the birth of cinema in the late nineteenth century, the search for Jesus has fascinated, inspired, and even frustrated countless film artists. This evolving tradition raises novel questions about Christianity's central figure while mirroring the social, political, cultural, and religious worlds in which his story is appropriated and consumed. For the best part of six decades, the epic spectacular played a dominant role in the interpretation and representation of Jesus in cinema. According to one urban legend, Cecil B. DeMille's The King of Kings (1927) left such an impression on one American minister that in a conversation with the film's leading 
man, the renowned silent actor Henry B. Warner, the minister remarked that every time he spoke of Jesus his thoughts turned to the actor's face.

For generations of viewers, The King of Kings was the definitive "cinematic gospel." The film combines fiction and melodrama with an appeal to biblical authority and the familiarity of Christian art and imagery. DeMille's Jesus is a universal and authoritative figure who offers reassurance in a time of flux. Stalked by DeMille's long shadow, no American filmmaker engaged the Jesus theme for the best part of three decades. On the eve of the cold war, Nicholas Ray revisited the story in King of Kings (1961). Unlike DeMille's more sentimental and melancholic vision, Ray departs from the devotional tone of the epic genre, covertly embedding questions of skepticism, secularization, and pluralism into his narrative. Both films exemplify the unity and diversity of the genre while equally demonstrating its tradition-forming role in the popular religious imagination.

This article explores the hermeneutics of the biblical epic and, further, reflects on cinema itself as a site of christological and hermeneutical reflection. Culture, tradition, and the emergence of conflicting interpretations exert a key influence over the genre. The epic is equally an autonomous and recognizable cinematic style. Indeed, it is often derided for its lavish aesthetic or nostalgic storytelling. Against this backdrop, the generic world of the epic appears uniform, but each film proliferates competing interpretations and reflects the social, political, and cultural worlds in which it emerges. The epics re-present and reimagine centuries of aesthetic interpretation on the Jesus theme.

Not only do they re-present this tradition, they reshape and transform it as it is socialized in new contexts. In this sense, the genre revives the quest for the true image, the Vera Icon. If DeMille and Ray picture Jesus in contrasting ways, each shaped by and shaping the world in which they tell their stories, so, too, do they rewrite and reinterpret the New Testament itself. Cinema shares in a process of interpretation that encompasses the oral and literary gospels alongside the two millennia of interpretation and representation through many media that follow. Thus, DeMille and Ray are part of a broader hermeneutical dynamic that shapes the Christian imagination.

By the same token, each film imagines the Jesus story for a particular time and place. Through the prism of American Christianity's encounter with secular modernity, DeMille and Ray explore the changing meaning of the Christian story. This crucial subtext influences each director's representation of religious experience, attitudes to belief, the resurrection, and the identity of Jesus himself. Despite the genre's upbeat and sometimes devotional tone, this conversation with and within culture gives each interpretation an uncertainty and an ambiguity. Beneath the excess, surge, and splendor of the epic, then, lies a complex hermeneutic that illustrates both the effect of the genre, as a medium of representation, on the Jesus story and, simultaneously, the changing backdrops against which Jesus is interpreted. DeMille and Ray reimagine their subject matter, reactivate its influence 
in the present, and demonstrate the role of cinema in the formation and mediation of the Christian story. Filmic interpretation reimagines, sometimes questions, and expands that story through the illumination of the screen.

\section{Questions of Genre}

Filled with lavish scenery, melodrama, and no small amount of sentimentality, the biblical spectaculars established a ubiquitous style for representing both Jesus and other sacred figures in cinema. A hybrid art form, the genre derives from the popular artistic, theatrical, and literary traditions of European Christianity. Its visual template re-presents works from the renaissance, baroque, and Victorian eras of religious art, while its theatricality and mingling of scripture with fiction owes much to the passion play traditions of medieval Europe. Each film appeals to a combination of scriptural fidelity, perceived Christian orthodoxy, and historical objectivity. By the same token, the genre introduces specific modes of representation and interpretation, which exert a profound influence over the Christian story and its sources of expression.

Grounded in a hyper-formalist style of filmmaking that often discourages realism, the historical setting of the epic may be nominally ancient but is often anachronistic, timeless, or imprecise. Each film constructs an internal universe that is grounded in a type of wish fulfillment or what Pamela Grace calls "miracle-time." This is a world where good inevitably triumphs over evil and a divine presence ruptures the ticking clock of chronological time. Nostalgic and sometimes kitsch in tone, the genre reached the peak of its popularity in the mid-twentieth century only to decline markedly throughout the late 1960s and early 1970s. Its style and structure, however, exert a seminal influence which still resonates in contemporary cinema.

The epics edit and reshape the New Testament to match both their implied or ideal audiences and the sociocultural backdrop against which they interpret the Jesus story. DeMille, for example, combines biblical quotations in the authoritative style of the King James Bible with fictitious scenes and characters. His prologue famously depicts the decadent pre-conversion life of Mary Magdalene. Reimagined as Judas Iscariot's erstwhile lover, she sets out to retrieve him from the grip of the carpenter. In an ironic twist, DeMille uses the Lukan story of Magdalene's possession by seven demons to illustrate her conversion from decadence to domesticity. Her exorcism dramatizes a conversion from dangerous promiscuity to a patriarchal Christianity, embodied in Henry B. Warner's authoritative and virile portrayal of Jesus. This mingling and interpretation of sources combined with the depiction of latent sexual deviancy ensured both the film's popularity and DeMille's status as an architect of the genre. Ray continues this fictionalization dynamic in his depiction of Barabbas and Judas Iscariot. Both are reimagined as revolutionaries battling against Roman rule. Depicted as the "messiah of war," Barabbas becomes the story's antagonist.

${ }^{1}$ Pamela Grace, The Religious Film: Christianity and the Hagiopic (New Approaches to Film Genre; Oxford: Wiley-Blackwell, 2009) 5. 
In each film, the New Testament becomes a template for more creative, even extravagant, imaginings of biblical figures.

Historically, each narrative inhabits a dual location. On the one hand, the genre offers a simulacrum of first-century Palestine but, on the other, "has its own precise contemporary location, through which the Christ narrative touches contemporary concerns." "2 The subject matter may be ancient but its subtexts are contemporary. By embedding contemporary issues into the story, each film demonstrates an awareness of its status as a "late text." To present the past, it seeks resonances in the present. The epic layers time in a two-way movement between the past and its interpretation in the present. Within this dynamic, it constructs "a singular kind of fictional spacetime configuration," as Grace puts it, which re-mediates the Jesus story via the social and cultural worlds within which it is consumed and appropriated. ${ }^{3}$

Unlike the so-called "Christ-figure" motif, where "secular heroes attain Christlike status, suffer analogues of the Passion, or die in cruciform pose," the Hollywood gospels are defined by an unambiguous, explicit, and mimetic focus on the person of Jesus. ${ }^{4}$ This dynamic often leads to an excessive idealization or objectification of Jesus. To maintain a formal acceptance of Jesus's divinity, for example, each film either idealizes him or overplays aspects of his otherworldliness. DeMille, for instance, consistently pictures Jesus with a light emanating from his face; in the crucifixion sequence, he suggests that Jesus possesses an almost superhuman capacity for pain as he is nailed to the cross. In another iteration, Ray idealizes his physical form in the passion sequence, where Jeffrey Hunter's chest is bizarrely shaven. Unlike DeMille, however, Ray's visual style is more muted and does not offer any overt indicators of Jesus's divinity.

The genre's sustained focus on Jesus is also the source of its critical dishonor. The celebrated film theorist André Bazin sees the mimetic focus of the Hollywood epics as the source of their "religious insignificance." ${ }^{5}$ Highlighting the visual excess of the genre, he argues that the film artist must dismantle Christian iconography in a kind of cinematic via negativa:

Almost everything that is good in this domain [cinema] was created not by the exploitation of these patent affinities, but rather by working against them: by the psychological and moral deepening of the religious factor as well as by the renunciation of the physical representation of the supernatural and of grace. As for "mysteries," the cinema has been able to evoke only those of Paris and New York. We're still waiting for it to deal with those of the Middle Ages. ${ }^{6}$

\footnotetext{
${ }^{2}$ Bruce Babington and Peter Evans, Biblical Epics: Sacred Narrative in the Hollywood Cinema (Manchester: Manchester University, 1993) 102.

${ }^{3}$ Grace, The Religious Film, 5.

${ }^{4}$ Babington and Evans, Biblical Epics, 110.

${ }^{5}$ Bert Cardullo and André Bazin, "Cinema and Theology: The Case of Heaven Over the Marshes," Journal of Religion \& Film 6 (2002), http://digitalcommons.unomaha.edu/jrf/vol6/iss2/15.

${ }^{6}$ Ibid.
} 
A similar critique comes from Paul Schrader, who describes Hollywood's directness of presentation as a fascination with vicarious heroes. Couched in religious imagery, the epic indulges fantasies and delusions. The sacred becomes a spectacle of "identification rather than confrontation."7 "For an hour or two," he continues, "the viewer can become that suffering, saintly person on screen; his personal problems, guilt and sin are absorbed by humane, noble, and purifying motives. The spiritual drama . . . becomes an escapist metaphor for the human drama." "Seen in this light, the Hollywood gospels represent an unsatisfactory, at best, or illegitimate, at worst, medium of the Christian tradition. Schrader's idealized model of cinema takes a somewhat dualist attitude and relies on the hypothesis of a universal spiritual style. This downplays viewer involvement and sets up an almost impossible set of criteria for religiously credible cinema.

While Bazin and Schrader's criticisms are both understandable and valid, they miss two important aspects of the genre. First, the Hollywood epics contain an intra-stylistic diversity that often goes unnoticed. Both DeMille and Ray offer contrasting interpretations of Jesus, thus emphasizing, secondly, the genre's status as an important indicator of the Christian story's reception history. New social and political contexts dictate the need for sometimes novel readings of the gospel story. Cinema lies at the vanguard of this dynamic, and the epic's unabashed depiction of popular Christianity and its encounter with modernity makes it an important, and unavoidable, moment in Christianity's encounter with culture. DeMille arguably establishes the social, political, and indeed religious dominance of the epic genre but Ray uses the format to covertly critique its form and function. Grace describes King of Kings as an example of "anti-spectacle," where spectacle critiques itself. ${ }^{9}$ Focusing on human interaction over enormous imagery or dazzling miracles, Ray moves from the spectacular to the intimate. His prologue depicts Rome's conquest of Judea in 63 BCE. Accompanied by a soundtrack that recalls a military march, Roman armies pour into Jerusalem. But the film incrementally undermines this structure. Its mise en scène combines a focus on personal interactions with less spectacular and progressively more intimate imagery. In so doing, Ray induces the genre with a sense of doubt and openness.

While encompassing common stylistic and structural templates, both artists proliferate conflicting interpretations of their subject matter, and this highlights how the epic is never a static medium of representation. Like the Christian story itself, it is a historical experience and thus never immune from social or cultural circumstances. Each work is a "cultural moment," where the Christian story expands into a broader artistic and cultural matrix. These competing interpretations both feed into and are shaped by the genre. As Jesus's story is re-consumed, that story re-consumes cinema, gets inside its skin, and continues the story's influence via

\footnotetext{
${ }^{7}$ Paul Schrader, Transcendental Style in Film: Ozu, Bresson, Dreyer (Berkeley: Da Capo, 1972) 164.

${ }^{8}$ Ibid.

${ }^{9}$ Grace, The Religious Film, 65.
} 
a new idiom. Amid the mysteries of Paris and New York, to paraphrase Bazin, we might return to older mysteries and find them transformed, even transfigured, through the post-modern sanctuaries of cinema.

\section{The Vera Icon}

From the inception of the art in the late-nineteenth century, the cinematic image of Jesus provoked controversy and fascination in equal measure. As early as 1907 , Pathé's La Vie et la passion de Jésus Christ was banned in Russia after the Orthodox Holy Synod objected to the film's release on the grounds that photography was an inadequate, even derogatory, medium of the gospel story. ${ }^{10}$ An edited version of the film was eventually released. But, in a telling gesture, the Synod recommended that those in attendance remove their hats. ${ }^{11}$ This sign of reverence implicitly recognized cinema as a viable, if contested, medium of the Christian story.

The Synod's anxieties are a reverse revival of the legend of Saint Veronica who, according to popular tradition, received a miraculous image of Christ's face as he walked to his death: A "memento," as Paul Coates writes, "becoming a memento mori." ${ }^{12}$ Between the visible and invisible, cinema makes what is absent present. While its photographic dimension offers the illusion of immediacy, it is always already a mediation. As Joseph Marty puts it, "it is a little of what it represents while not really being it." ${ }^{13}$ For Christian denominations, the rise of cinema presented both a challenge to authority and the possibility of confusion. The image of Jesus was no longer the preserve of a particular tradition. Now mediated via the screen, the filmic Jesus, embodied in an actor, could not only challenge but change meaning.

Two millennia of art and representation on the Jesus theme permeates cinema. Film artists not only curate this matrix of images and stories but equally reconstruct and recreate this tradition. Within this dynamic, neither film artist nor film viewer are in full or final control of any image's meaning. Instead, meaning emerges through an encounter, and, like conversations between people, something new, or unknown, arises in the filmic search for the image of Jesus. Since the mid-twentieth century, the concept of "the Gaze" has played a key role in the study of visual culture. Diane Apostolos-Cappadona describes it as "neither a protracted nor intensified mode of looking" but a way of looking in itself, which "presumes that there is a right and a wrong way to look: intuitively, culturally, politically, and engendered." ${ }^{14}$

\footnotetext{
${ }^{10}$ Jolyon Mitchell, "Understanding Religion and Film in 'Post-Secular' Russia," in Religion in Contemporary European Cinema: The Postsecular Constellation (ed. Costica Bradatan and Camil Ungureanu; Routledge Studies in Religion and Film; London: Routledge, 2015) 186-198, at 188.

11 Ibid.

${ }^{12}$ Paul Coates, Cinema, Religion and the Romantic Legacy (Aldershot: Ashgate, 2003) 203.

13 Joseph Marty, "Toward a Theological Interpretation and Reading of Film: Incarnation of the Word of God-Relation, Image, Word," in New Image of Religious Film (ed. John R. May; Communications, Culture and Theology; Wisconsin: Sheed and Ward, 1997) 131-50, at 132.

${ }^{14}$ Diane Apostolos-Cappadona, "Iconography," in The Routledge Companion to Religion and Film (ed. John Lydon; London: Routledge, 2009) 443.
} 
When socialized through cinema, it "becomes the recognizable history of shared memory and communal identity that grounds both the visual power of the film and our reception of it." ${ }^{15}$ This memory and identity, further, become our own, "through the iconography which illuminates the screen before us." ${ }^{16}$ DeMille and Ray's revisualizations of Jesus not only communicate a particular interpretation but equally share in a broader dynamic of representation. Through viewing, this shared heritage becomes our own and we participate in its meaning. An exploration of DeMille and Ray's visual framing of their protagonist reveals how they socialize the Jesus image and, perhaps, vindicates the Holy Synod's fear of cinema.

DeMille's celebrated "revealing" of Jesus occurs through the healing of a blind child. As she feels her way through a crowd, another child, later credited as the young evangelist John Mark, takes her by the hand and helps her through a window where an angelic, motherly figure awaits. She leads the girl through a crowded house. Then a quotation from the Gospel of John in the authoritative tone of the King James Bible appears: "I am come a light into the world, that whosoever believeth in me shall not abide in darkness" (John 12:46 KJV). Our sight becomes unified with the girl's. At first there is only darkness but, slowly, it turns to light. We are greeted by her first vision: the face of Christ bathed in heavenly light. Filling the screen in close-up, the savior appears virile, paternal, and patriarchal. He smiles at the girl and then us, as a father would to his child.

Influenced by the devotional art of Gustave Doré and James Jacques Tissot, DeMille's filmic iconography projects authority, assuredness, and the illusion of immediacy. Aged in his mid-fifties at the time of filming, Warner's Jesus represents patriarchal stability and an "extreme iconicity and familiarity of gesture." ${ }^{17}$ The scene replicates a visual devotional culture that was familiar to its implied audience and rooted in the aesthetic and liturgical traditions of Victorian Christianity. An omnipresent, personal savior, DeMille's Jesus carries an aura of universality. The film's "tableauesque style" and "constant stasis of compositions and poses" evokes a familiar world of representation but simultaneously de-historicizes Jesus. ${ }^{18}$ This dynamic comes to a crescendo in the resurrection scenes. Beginning with the meeting of Jesus and Mary Magdalene in the garden and culminating in an ascension scene, Jesus transcends history. The resurrection sequence is initially shot in color, a technique that further detaches Jesus from the vagaries and anxieties of the "ordinary" world. The popular hymn Jesus Christ is Risen Today accompanies the scene, which lends the episode a quasi-liturgical quality. In the final scene, Jesus blesses the remaining apostles as he ascends into heaven. The background then changes to a modern industrialized city and another quotation appears: "Lo, I

\footnotetext{
${ }^{15}$ Ibid.

${ }^{16}$ Ibid.

${ }^{17}$ Babington and Evans, Biblical Epics, 119.

${ }^{18}$ Ibid.
} 
am with you always" (Matt 28:20 KJV). The intimate and paternal Jesus transcends history, offering assurance and stability to a world in flux.

If DeMille emphasizes universality, Ray reverses the dynamic. Highlighting ambiguity over certainty, King of Kings imagines Jesus as a more historical figure. Aged in his mid-thirties during filming, Jeffrey Hunter's protagonist is more youthful, uncertain, and even brooding. The historically focused prologue prepares viewers for this by framing Jesus via the distance, authority, and specificity of secular rather than biblical history. Ray not only pictures Jesus in a less authoritative manner but equally emphasizes his absence from the screen at various, and sometimes crucial, points in the story. In the baptism sequence, Hunter's first appearance, Ray introduces a series of detraditionalized and destabilizing visual tropes. First, he pictures Jesus from above rather than below, thus depriving him of visual authority. Secondly, Ray uses a full screen shot of Jesus's eyes to emphasize his authority and charisma. Highlighting human understanding over divine authority, this motif suggests an open interpretation of Jesus's identity.

Ray accompanies the image of Jesus's eyes with a recurring shot of his silhouette. An established technique of the Roman-Christian and Jewish epics of the 1950s, such as Quo Vadis (1951) or Ben-Hur (1959), the motif indicates an ambiguous presence. In earlier films, its use reflects a respectful reticence toward the image of Jesus. Ray's use of the technique furthers his "anti-spectacle" style. In two of his three miracle episodes, the "healing shadow" occurs, suggesting ambiguous, psychosomatic, or naturalistic explanations. This reaches a crescendo in the final resurrection sequence, which, like DeMille, is built around a double structure. A brief meeting with Mary Magdalene is accompanied by a final scene where Jesus appears to the remaining disciples. As choirs of angels sing, itself a staple of the genre, the disciples loiter on a beach. The risen Jesus appears as a shadow that intersects with a fishing net to form a cruciform shape. Unlike DeMille's avowedly corporeal resurrection, Ray disembodies Jesus and renders him as a talisman. The "messiah of peace . . . lives on in non-bodily form that intersects with the tangible world." 19 The search for a true image remains open and incomplete. DeMille's intimate iconography gives way to a structuring and talismanic absence.

\section{Rewriting the Gospels}

If the Jesus epics reimagine the tradition of picturing Jesus, their storytelling dynamics play with the boundaries of the literary gospels. First, they harmonize and fictionalize the New Testament. Appealing to an aura of reverence, they conflate scripture with history uncritically. DeMille's introduction epitomizes this approach while Ray updates it subtly. The King of Kings opens with a title card stating how the events portrayed took place two millennia ago. Reinforcing the point, DeMille adds a claim that his work is equally an act of evangelization: both

${ }^{19}$ Grace, The Religious Film, 77. 
a faithful representation and an exhortation toward faith. Relying less on direct quotations, Orson Welles's narration in King of Kings nonetheless begins with the words, "and it is written." This gives the filmic "text" a parallel status with both scripture and ancient history. Each film takes liberties with the New Testament and uses cinematic techniques to authorize more imaginative accounts.

The dual location of each film embeds contemporary attitudes into its reading of an already hybrid New Testament. Judaism, for example, rarely functions as anything other than a forerunner to Christianity. DeMille, notably, adopts an almost entirely hostile approach to Judaism. Caiaphas, the High Priest, bears all the characteristics of an anti-Semitic caricature, while the temple's collapse as Jesus dies signals a triumphant and Christianized reading of Second Temple Judaism. Working out of a post-Holocaust perspective, Ray counters this dynamic in his prologue, which dwells on the suffering of the Jewish people under Roman rule. The scenes, further, draw a clear parallel between the Jesus story and more recent events in the images of lifeless Hebrew bodies dumped on a bonfire. In another feature, Judaism and Christianity function as prototypes of Western liberal democracy. DeMille's account of Jesus's ministry omits any criticism of wealth, thus vindicating the predominant political and economic culture of America in that period. Ray's story, similarly, explores the anxieties of the Cold War world. The opposition between Jesus and Barabbas reflects the anxious choices of peace versus war and interior versus exterior change facing American culture in that period.

This hybridity of ideas and styles creates a series of tensions. The epic is fundamentally fictional, as Adele Reinhartz points out, "which in turn creates an unresolved tension with the historicity of the subject or hero, and the broader claims to historicity that these films make or imply." ${ }^{20}$ Rather than resolving these tensions, the epic consciously draws them out. As it holds the past and the present in a tension, it mirrors the wider process of interpreting the Christian story itself. Just as the past and present are held in this manner, so too are the diverse readings of the Christian story. The gospel is both one story and four, while the subtexts at play in its reception prompt a plurality of interpretations. A reading of cinema's New Testament that expects biblical fidelity, therefore, is bound to be disappointed, but cinema is never a substitute or direct "translation" of its sources. The image "necessarily interprets as well as portrays - all the more when it is consciously used to present persons or events in a context different from the scriptural narratives." ${ }^{21}$ The scriptural Word shares a complementary relationship with the image. Even as the technological, economic, and secular dimensions of cinema create new challenges for theological reflection, they are nonetheless rooted in a hermeneutical dynamic that, likewise, permeates the Christian story's expansive landscape. As

\footnotetext{
${ }^{20}$ Adele Reinhartz, Bible and Cinema: An Introduction (Abingdon: Routledge, 2013) 64.

${ }^{21}$ Richard Viladesau, Theological Aesthetics: God in Imagination, Beauty, and Art (New York: Oxford University Press, 1999) 168.
} 
Hollywood reinterprets Jesus, so, too, is that story reactivated in the present through a hybrid genre which both interprets and re-presents the story.

The epic not only re-presents pre-existing material but weaves its content into a unique temporal experience. As Vivien Sobchack writes, "Hollywood historical epic - through repetition - calls the most explicit, reflexive, and self-authorizing attention to its existence as a re-presentation." 22 Voice over narration, calligraphic titles, and exotic locations repeat and re-present the subject matter, projecting it into the world(s) of viewers. DeMille, for instance, liberally quotes biblical verses in the title card format, thus claiming "the anonymous authority the written word has secured in our particular culture." ${ }^{23}$ His liberal approach to scripture, however, fragments, repositions, and expands the biblical story. In so doing, he seeks a certain legitimacy for his interpretation. ${ }^{24}$ In the sound and color format, Ray uses Welles's narration to establish a transcendent authority over the story. Simultaneously, King of Kings destabilizes this dynamic by incrementally replacing Welles with the character of Lucius who internally mediates the story. Ray dramatically integrates a form of re-presentation into the film. Both omniscient and internal forms of storytelling extend meaning, refusing to repress the Jesus story as an artefact. For Sobchack, narration adds "an additional textual level that temporally extends emplotment of the story from the past to the present and confers significance on the story from the present to past." 25 This two-way dynamic authorizes the film and reactivates its subject matter in the present. The epics are textual layers, therefore, which extend the meaning of the Christian story itself.

\section{Louis-Marie Chauvet and the Canonicity of Scripture}

Neither a peripheral commentary nor a didactic explanation, the Hollywood gospels mirror and partake in the mediation of scripture itself and emplot its significance into the present. The way in which a social body retells its stories illustrates how those texts are never stable entities immune from historical or social circumstances. The French theologian Louis-Marie Chauvet offers an important illustration of how the status of scripture is itself the product of a complex, often unstable, process. ${ }^{26}$ No text is sacred in and of itself; rather, "the social body recognizes itself, consciously or not, officially or not, in the texts." ${ }^{27}$ Taking his cue from the work of Roland Barthes, Chauvet argues that all texts emerge from and are consumed

${ }^{22}$ Vivien Sobchack, “'Surge and Splendor': A Phenomenology of the Hollywood Historical Epic," Representations 29 (1990) 24-49, at 34 [italics in original].

${ }^{23}$ Ibid.

${ }^{24}$ See Vivienne Westbrook, "The King of Kings (DeMille Pictures, 1927): The Body and the Word on Film," in The Silents of Jesus in Cinema: 1897-1927 (ed. David Shepherd; Routledge Studies in Religion and Film; New York: Routledge, 2016) 256-270.

${ }^{25}$ Sobchack, "'Surge and Splendor,"” 34 [italics in original].

${ }^{26}$ See Louis-Marie Chauvet, Symbol and Sacrament: A Sacramental Re-Interpretation of Christian Existence (trans. Patrick Madigan, SJ, and Madeleine Beaumont; Collegeville, MN: Liturgical, 1995).

${ }^{27}$ Ibid., 208. 
within a particular world. ${ }^{28}$ Thus they are never the product of "a neutral place that sovereignly transcends all socio-historical determinations." ${ }^{29}$

The formation of the canon illustrates this dynamic. In Symbol and Sacrament, Chauvet outlines three interwoven levels of canonicity that rely on the relationship between the social body and the text. He illustrates "canon 1" through the example of ancient Israel's tribal traditions and the hypothetical sources at work in the Pentateuch. This is the "corpus, first oral, then written, which already functions as a practical canon of the traditions in which a clan, a tribe, or a group of people recognize and identify themselves." ${ }^{30}$ This first canon partakes in and is reshaped by "canon 2," the "instituting tradition," which "designates the hermeneutical process of rereading-rewriting canon 1 in relation to constantly changing historical situations. ${ }^{31}$ Before the formalized literary text there are oral traditions, diverse origin stories for particular groups, and competing accounts. The written text emerges through interpretation and inspires more "texts" through a variety of media. To illustrate the point more clearly, Chauvet builds his analysis on the BulgarianFrench philosopher, Julia Kristeva's distinction between the "pheno-text" and "geno-text." ${ }^{2}$ The "pheno-text" is the apparent text of canon 1 "woven secretly" by a hermeneutical "geno-text," the hidden and creative text of "canon 2." The "unwritten" geno-text interprets "canon 1" in light of new realities or contexts, thus rewriting the "instituted tradition." Both traditions rely "on a third element: the events recognized as foundational." ${ }^{33}$ This third level of canonicity layers another level of textuality. Nowhere is this process more apparent than in the formation and sacralizing of myths and sacred or religious texts:

\begin{abstract}
We may say that the definitive setting of the canon of "holy books" is the ultimate unfolding, at the level of the pheno-text, of a process of canonicity constitutive of the geno-text, a process which manifests the essential relation of the reading body to the text. The process is at work in every text, but particularly in the myths and in the books held sacred by various religious groups. ${ }^{34}$
\end{abstract}

\footnotetext{
${ }^{28}$ Chauvet builds his argument on the "semio-linguistic theory of the text" as outlined in Barthes' contribution to Encyclopaedia Universalis (Roland Barthes, "Texte, Théorie du," Encyclopadia Universalis, http://www.universalis.fr/encyclopedie/theorie-du-texte/).

${ }^{29}$ Chauvet, Symbol and Sacrament, 205.

${ }^{30}$ Ibid., 201.

${ }^{31}$ Ibid.

${ }^{32}$ Barthes, "Texte, Théorie du."

${ }^{33}$ Chauvet, Symbol and Sacrament, 208.

${ }^{34}$ Ibid. 208 [italics in original]. The original French quotation is helpful here: "En reprenant le couple «géno-texte»-«phéno-texte» de J. Kristeva, nous pouvons dire que cet établissement du canon des «livres saints» est le déploiement ultime, au niveau du phéno-texte, d'un procès de canonicité constitutif du géno-texte, procès qui dénote le rapport essentiel du corps lecteur au texte. Un tel rapport vaut pour tout texte, mais il atteint une prégnance particulière dans les livres tenus pour sacrés par les groupes religieux et dans les mythes" (Chauvet, Symbole et Sacrement: Une Relecture Sacramentelle de L'existence Chrétienne, [Paris: Les Éditions du Cerf, 1987] 214).
} 
If we accept Chauvet's contention, then cinema expands biblical interpretation into the world of popular culture. Likewise, filmic interpretation extends the story's own history of influence. Like the unwritten "geno-text," cinema interprets the origin stories of the Christian "body" in light of changing social and cultural dynamics. DeMille laments the burgeoning secularity of a more industrialized, technologically saturated, and materialistic world. Ray, too, reimagines Jesus for a more uncertain time, where DeMille's fears are, perhaps, realized. Moral skepticism, pluralism, and unbelief have taken hold. Jesus becomes a contested figure, remediated through the fictitious characters who reinterpret him for viewers of many opinions. Cinema profoundly shapes viewer perceptions, potentially shifting, expanding, or even changing the story itself. As it rewrites the Christian story, cinema moves scripture "beyond itself in ways that reflect and indeed create new cultural realities." 35

The New Testament texts are "multi-dimensional" spaces, to borrow Barthes's words, "in which a variety of writings, none of them original, blend and clash." ${ }^{36}$ The audio-visual bible(s) of cinema neither replace nor efface the Christian story but rather expand and extend its influence. Cinema is an intertextual space, where "a tissue of quotations drawn from the innumerable centers of culture" meet ${ }^{37}$ If Barthes's post-structural tone problematizes the stability of the text, it is worth noting that the New Testament itself holds no such certainty. It "is a tissue of citations, explicit or implicit, from written and oral traditions of the Old Testament, reread as accomplished in Christ." ${ }^{38}$ Thus, we can speak of an "instituting tradition" in both Judaism and Christianity, which rereads and rewrites the nascent oral and literary traditions in "relation to constantly changing historical situations." ${ }^{39}$ The formation of the Judeo-Christian bible is a hermeneutical process that continues beyond the literary New Testament into the worlds of popular and devotional art, musical interpretation and reflection, and cinema itself.

Cinema, then, only amplifies the hermeneutical dynamic at the core of the Christian story. As urbanized, technologically saturated society experiences rapid change, so too does its ways of representing itself to itself via the shared heritage of its cultural myths. While Hollywood's treatment of the Jesus story engages in fictional speculation, it only does so as the inheritor of a tradition which itself recognizes the instability of scripture. Products of the oral tradition, the literary gospels are interpretations rather than originals. The centuries of aesthetic, literary, and musical interpretation that follow form an essential part of this dynamic. Cinema's multiple and hybrid texts rewrite the Christian story and, in so doing, alter our understanding of that story and its sources of expression.

${ }^{35}$ David Shepherd, "Hollywood's Bible and Beyond" in Images of the Word: Hollywood's Bible and Beyond (ed. Shepherd; SemeiaSt 54; Atlanta: Society of Biblical Literature, 2008) 1-9, at 6.

${ }^{36}$ Roland Barthes, "The Death of the Author," in Image Music Text (ed. and trans. Stephen Heath; London: Fontana, 1977) 142-48, at 146.

${ }^{37}$ Ibid.

${ }^{38}$ Chauvet, Symbol and Sacrament, 195.

${ }^{39}$ Ibid., 201. 


\section{Secular Gospels}

DeMille and Ray appeal to the credulity of belief while simultaneously negotiating a series of challenges to faith. Both directors formally accept the divinity of Jesus, the credibility of miracles, and the historical reliability of the New Testament. Each film simultaneously depicts an encounter between Christianity and secular modernity as much as, if not more than, any first-century dynamic. Alongside this intradiegetic element, it is important to note that cinema itself lies at the penumbra between the secular and religious. The capitalist, technological, and entertainmentbased dynamics of cinema locate it firmly within what Charles Taylor calls "secular time." 40 That is, the "ordinary" world with its basic chronological progression of temporal events. The way cinema creates meaningful worlds, however, puts it on a par with religion (at least at the immanent, formal level). In this sense, cinema revives the romantic notion of aesthetic expression as a quasi-religious experience. As Taylor puts it, the "awe we feel before artistic originality and creativity places art on the border of the numinous, and reflects the crucial place that creation/ expression has in our understanding of human life." ${ }^{41}$ While cinema's reliance on photography means that it lacks certain elements of either painting or poetry, its world-making dimension reflects the romantic ideal.

Before exploring how DeMille and Ray dramatize this encounter, it is helpful to engage with some of Taylor's key categories in their own right. In A Secular Age, he outlines the states of mind that shape this so-called "disenchanted" order. The dialectic between modernity and tradition portrayed by the epics mirrors the interface between what Taylor describes as "open" and "closed" forms of secularity. We no longer believe that divine, spiritual, or demonic agents directly shape and guide our world. If we still have faith, it is more than likely fused with an awareness that belief is one choice among many. Facets of our culture see these "vestiges" of enchantment as a threat. In response, a more materialist view of life proffers "closed world structures" where the divine, mysterious, or sacred becomes a threat to human flourishing. This transition from an enchanted to disenchanted order results in the "Immanent Frame," which is rooted in a distinction between an inner and outer world or the "buffered" and "porous" self. The "buffered" self gives us a firm border between self and other. All "thought, feeling, and purpose, all the features that we normally ascribe to agents, must be in minds, which are distinct from the 'outer' world." ${ }^{42}$ It would seem, in this light, that "the idea of spirits, moral forces, causal powers with a purposive bent" have become "close to incomprehensible." ${ }^{43}$ This genealogy of ideas exerts a profound, if contrasting, influence on DeMille and Ray as they reinterpret Jesus. Two common themes emerge here. First, each director

${ }^{40}$ Charles Taylor, A Secular Age (Cambridge, MAn: Belknap Press, 2007) 54.

${ }^{41}$ Taylor, Sources of the Self: The Making of Modern Identity (Massachusetts: Harvard University, 1989) 376.

${ }^{42}$ Taylor, A Secular Age, 539.

${ }^{43}$ Ibid. 
portrays modern character types who address viewers of varying degrees of belief or unbelief. Second, both films engage the question of religious experience in their depiction of miracles and their climactic resurrection sequences.

Following the generic conventions of the epic, DeMille and Ray expand aspects of the Jesus story through either fictitious characters or the fictionalization of biblical figures. These decidedly modern, often sophisticated, characters address viewers of varying degrees of belief and unbelief and, thus, bridge a gap between the ancient story and the modern world. Each embodies modern ideas and, on occasion, a sense of loss or nostalgia for belief. Figures such as Mary Magdalene, Judas Iscariot, Barabbas, and Pontius Pilate, among others, voice contemporary attitudes for or against faith. Ray takes this a step further in his Lucius character. An almost total fictionalization, based loosely on the centurion who attends the crucifixion, Lucius chronicles Jesus's ministry and mediates him in a sympathetic yet neutral manner for an implied audience caught between the optimism and melancholy of secularization.

While couched in a simulacrum of first-century Palestine, Ray and DeMille's stories are decidedly modern. Their projections of secularity, however, differ markedly. DeMille's "secular" characters, embodied primarily by Judas Iscariot, Caiaphas, and Pontius Pilate, are depicted in a uniformly negative light. They are either greedy, lustful, or politically weak. Only Mary Magdalene truly converts and in a less than subtle indicator of the film's moral stance, she abandons a life of decadent freedom for patriarchal domesticity. Thus, DeMille's messiah redeems secularity from its excesses. By contrast, Ray's modern trio of Barabbas, Judas, and Lucius offer contrasting, and conflicted, responses. Each is caught in an inevitably tragic crossfire of beliefs and ideologies. Lucius, for example, is sympathetic toward Jesus's decidedly enlightenment ideals of pacifism and human unity. In one scene, he reads the miracles of Jesus aloud in the form of a report. An incredulous Pilate grabs his "script," tosses it into a pool, and reminds his court that there are no such things as miracles, "only fools who believe in them." In a telling sequence, Pilate's equally fictionalized wife, reimagined as a daughter of Caesar, stoops low, takes the script from the pool, and returns it to Lucius. When questioned about his own beliefs, Lucius admits that his experience as a soldier "is proof enough to me that there can be no God." After attempting to defend Jesus during his trial, he returns to the biblical narrative as he oversees the crucifixion. Joined by Pilate's wife at the cross, he utters a variation on the biblical confession of the centurion. Their absences after this scene, however, leave their journeys to faith incomplete. If Lucius is sympathetic, Barabbas is Jesus's mythic antagonist. Reimagined as a "messiah of war," he preaches violence and external change against Jesus's ideal of inner, and modern, change. Caught amid a clash between politics and the spirit, Judas's fate becomes a tragic choice between two irreconcilable messiahs, each of whom embody the anxieties of Cold War America. 
Religious experience, particularly in the form of miracles, is crucial to the hermeneutics of the biblical epic because, as Babington and Evans admit, "whatever is done with them characterizes attitudes to the divine in a world under pressure from the attritions of modern science." ${ }^{4}$ DeMille and Ray's intra-stylistic diversity alongside the latter's move toward "anti-spectacle" intensifies this dynamic. For DeMille, Jesus's miraculous power reveals his divinity, and the first shot of Jesus, accompanied by a heavenly light, makes this explicit (albeit according to the conventions of Hollywood cinema). Similarly, Warner's Jesus performs only three miracles: the healing of the blind girl, a quasi-fictional exorcism of Mary Magdalene, and the raising of Lazarus. Following the Johannine narrative, the Lazarus miracle becomes the prime cause of the passion. By contrast, Ray's socalled "time of miracles" is less assured. Like DeMille, he includes only three: the exorcism of a demoniac, the curing of a lame child, and the healing of a blind man, each of which is open to naturalistic or psychosomatic explanations. In a striking departure from either cinematic "tradition" or the biblical accounts, Ray uses the eyes and shadow techniques as indicators of an ambiguous healing presence. Jesus's shadow falls over the blind man and lame child, while his eyes appear to calm the demoniac. Filled with plurality and ambiguity, the scenes are open to believers and unbelievers alike. This dynamic is made explicit not only in the scenes themselves but, perhaps more importantly, in how they are reported. Lucius's account of the miracles, as Grace observes, "carries out the conventional hagiopic functions of asking questions, expressing the opinions of nonbelievers, and forcing the viewer to wait for a resolution." ${ }^{45}$ More so than his generic counterparts, Ray leaves the question largely unresolved.

The resurrection scenes bring these questions to something of a crescendo but leave more questions than answers. DeMille's corporeal and unambiguous event universalizes Jesus but opens with a bodily and thus specific emergence of Jesus from the tomb. Ray's use of the shadow leaves his interpretation in a far more ambiguous space, suggesting, perhaps, that the disciples' experience may or may not be a disembodied, imagined voice. "The moment is readable orthodoxly, but ... the image is also open to interpretation as ... his influence rather than metaphysical ascent." 46 DeMille's imagery replicates a Christianity intimately familiar to his audience. In the shadows where interpretation takes hold, Ray highlights an emerging alienation between American institutional Christianity and the wider culture. In the shadows, Jesus's story remains incomplete. Understood in tandem with each other, both films contribute to an evolving, unfinished dynamic. Like the frame of belief, cinema's interpretation of Jesus remains open rather than closed.

\footnotetext{
${ }^{44}$ Babington and Evans, Biblical Epics, 103.

${ }^{45}$ Grace, The Religious Film, 70.

${ }^{46}$ Ibid.
} 


\section{Cinema as Reinterpretation}

Every Jesus film evokes different, and sometimes converging, aspects of its subject matter. Entering, interpreting, and shaping this matrix of meaning, the filmic tradition equally mediates a wider dynamic of representation and interpretation. The interpretive dimension of cinema tells us that rather than conforming to, or indeed deforming, a normative form of representation, the art discloses something new or unknown about its subject matter. This permeable relationship between cinema and its subject matter(s) reveals how the interpretive potential within any one character, story, or theme is inexhaustible. Hans-Georg Gadamer takes up this crucial element in his philosophical hermeneutics. While he never engages the filmic art directly, his penetrating reflections on aesthetic interpretation and historical understanding have profound implications for the relationship between cinema and the Christian story. Aesthetic hermeneutics reveals how works of art not only "re-interpret and re-present subject-matters but extend and alter their being. ${ }^{.47}$ Likewise, "the various interpretations of an art work share a sameness by addressing different aspects of that work's core concern or meaning." ${ }^{48}$ The meaning of cinema, one might say, rests in an encounter with the filmic work, its subject matter, and its multiple worlds. In that encounter, the very character of that subject matter is changed and transformed through its interpretation in a new context and via a new idiom. Further, viewers are potentially changed by their encounter with any one film.

Interpretation through any medium is never an attempt to decipher an "original" intention behind any work or theme. Aesthetic experience, rather, offers multiple ways of understanding its subject matters. For Gadamer, "all encounter with the language of art is an encounter with an unfinished event and is itself part of that event." ${ }^{49}$ No one image or story can ever capture the totality of the thing it represents. The varied versions of the Jesus story are not an obstacle in the search for a definitive interpretation. Cinema's openness, rather, challenges viewers to rethink their own preconceptions of its subject matter.

Gadamer's hermeneutics offers a vocabulary which allows us to encounter cinema as a medium that discloses the possibilities of the Jesus story. The Christian story, as a seminal event, exerts an influence over interpretation. Since meaning is hybrid, never complete, and always becoming, there are multiple possibilities at play. Indeed, there are multiple "Jesuses," which tell us how the potential of the subject matter remains inexhaustible. We, too, are part of this conversation, thus exemplifying how viewing is never passive but rather active, something into which we enter and participate.

\footnotetext{
${ }^{47}$ Nicholas Davey, "The Hermeneutics of Seeing," in Interpreting Visual Culture: Explorations in the Hermeneutics of the Visual (ed. Ian Heywood and Barry Sandywell; London: Routledge, 1999) 3-30, at 4.

${ }^{48}$ Ibid., 14.

${ }^{49}$ Hans-Georg Gadamer, Truth and Method, (trans. Joel Weinsheimer and Donald G. Marshall; 2nd rev. ed.; London: Continuum, 2004) 85 [italics in original].
} 
DeMille and Ray temper their creative interpretations of Jesus with a selfconsciousness of their historical distance from the story. Each film frames Jesus for a present where the distance of his story requires mediation. Further, both film artists influence the course of interpretation itself. This creates a double-layered dynamic where, on the one hand, each film re-mediates the past and, on the other, re-mediates and influences the tradition of representation and interpretation. In Truth and Method, Gadamer approaches the problem of the past via the concept of "temporal distance." ${ }^{50}$ Beginning with an appeal to the rehabilitation of tradition, he outlines how all understanding is "a process of transmission in which past and present are constantly mediated." ${ }^{51}$ The past, therefore, is never an object in need of retrieval. Rather, it is a continuous effect. The passage of time allows for fertile and creative interpretations of a story or character to emerge. Here, the significance of aesthetic hermeneutics and the historical character of interpretation converge. The creativity of art and its mingling of the past and the present demand that we rethink our relationship to the past. This means that tradition is never a static reality to which any one interpretation must conform; rather, "we produce it ourselves inasmuch as we understand, participate in the evolution of tradition, and hence further determine it ourselves." 52 The Jesus epic tradition provokes fascination, participation, and understanding through its intertextuality, where it interweaves with a variety of interpretive media. This alters both the subject matter itself and our understanding. Within this dynamic, cinema becomes the fertile ground upon which meaning happens. Temporal distance, as Gadamer puts it, "lets the true meaning of the object emerge fully. But the discovery of the true meaning of a text or a work of art is never finished; it is in fact an infinite process." 53 Thus, it reminds us that time itself "is no longer a gulf to be bridged because it separates; it is . . . the supportive ground . . . in which the present is rooted." 54

DeMille and Ray project the Jesus story into the present of its implied viewer(s) while, for the same reason, demonstrating the instability of the biblical text(s) they interpret. Their intertextuality demonstrates the opportunity of interpretation. As they mediate the gospels, they simultaneously mirror viewers' worlds and their involvement with and within that story. As each narrative effects viewers in their worlds, both viewer and subject matter potentially change. All interpretation occurs against the backdrop of our prior involvement in tradition. Cinema itself forms a tradition while simultaneously inhabiting a broader world of interpretation and representation through many media. A potent example of this is the way film artists reference one another while, similarly, mediating a broader extra-filmic tradition of representation. Ray, for example, implicitly and explicitly evokes

\footnotetext{
${ }^{50}$ Ibid., 291.

${ }^{51}$ Ibid.

${ }^{52}$ Ibid., 293.

${ }^{53}$ Ibid., 298.

${ }^{54}$ Ibid., 297.
} 
DeMille's imagery and style. Arguably, his more youthful protagonist, actualized in Jeffrey Hunter, springs from the assured virility of Warner's paternal savior. This indicates the emergence of a "canon" of sorts, within which DeMille exerts a seminal influence. For Babington and Evans, this marks Ray's film as a "double act of transgressive oedipal intertextuality," which replaces a fatherly Jesus with a filial and secular savior. ${ }^{55}$ Both films are stories about contemporary American, or Western, Christianity as it faces a panoply of challenges to its metanarrative. Their internal reliance on each other, likewise, is integral to a dialogue between cinema and the broader landscape of the Christian story. Seen in this light, they represent a coming to terms with cinema's openness and appeal for participation. Like the biblical narratives, they attempt "to faithfully render the identity of the characters to which the stories are ascribed, and in them our own possible identities." 56 Texts are never autonomous or self-referential. Instead, "they exist only when they are read. Texts and readers are mutually constitutive." ${ }^{57}$ As DeMille, Ray, and generations of film viewers reread and thus reimagine the Christian story through cinema, they realize its potential as a medium of the Christian tradition itself.

Gadamer's "rehabilitation" of tradition culminates in his insistence that it exerts a "claim" over us. Like a "Lutheran sermon" or "Catholic mass," tradition involves us in a proclaimed or significant narrative. DeMille, Ray, and their counterparts across the Jesus film tradition engage the gospel story via a medium and style that is unavoidably rooted in an encounter with and within the Christian tradition. In so doing, cinema brings us into a sense of "contemporaneity" with the story. Ray's talismanic savior figure, for example, and his paralleling of the cold war world with that of the New Testament illustrates how that story has meaning for a time beyond its temporal horizon and holds significance in the contemporary world(s) of viewers.

A "claim" is not so much the demand for a particular interpretation but rather its grounding. ${ }^{58} \mathrm{~A}$ claim lasts and can be enforced at any time. If we accept this contention, then the claim can be grounded, enforced, and fulfilled through any medium. Indeed, because it constitutes all interpretation this is a necessity. A faithful reading, then, is not so much one which acknowledges one interpretation over another but recognizes and, in so doing, honors the "claim." Each instance of the subject matter is an opportunity to find new meaning. The Jesus epics re-visualize the New Testament for an uncertain but no less creative time. Cinema interweaves with those texts and contexts in the search for meaning.

${ }^{55}$ Babington and Evans, Biblical Epics, 138.

${ }^{56}$ Gerard Loughlin, Telling God's Story: Bible, Church and Narrative Theology (Cambridge: Cambridge University, 1996) 153.

${ }^{57}$ Ibid., 156.

${ }^{58}$ Gadamer, Truth and Method, 123. 


\section{Conclusion: Plurality and Ambiguity}

I have examined the epics as media of christological and hermeneutical reflection. Their narrative structures and visual landscapes tell us something about the reception of the Christian story against the backdrop of evolving social, political, and cultural contexts. While rooted in a lavish, melodramatic, and devotional style, the genre offers contrasting interpretations of its subject matter. Each reimagines Jesus for a particular time and place but, by the same token, shares in the broader interpretive and representational landscape of the Christian tradition. The "gospels" of DeMille and Ray demonstrate the evolution of the Jesus epic from spectacle to so-called "anti-spectacle." While appealing to perceived Christian orthodoxy, each film contains anxious undertones, reflecting the encounter between American Christianity and secular modernity. DeMille negotiates this dynamic through a melancholic and reassuring vision that borders on a quasi-liturgical style of representation. Ray, in contrast, offers a covert critique of the epic's stylistic and, indeed, theological assumptions. Read in tandem, both films exemplify the dynamism of the Christian story. The biblical text(s), as Chauvet illustrates, exists through the social body who consume and reinterpret it. Cinema lies at the vanguard of this dynamic as the Jesus story is reimagined for a particular world, thus extending and expanding its influence. Finally, I have considered DeMille, Ray, and cinema more broadly through the lens of Gadamer's hermeneutics. Like the broader tradition of picturing Jesus, DeMille and Ray construct an intertextual interplay between the past and the present, skepticism and openness, the visible and the invisible. A hermeneutical appreciation of the epic liberates both the genre and cinema itself from the dualisms of word and image, the sacred and the secular, high and low art. In this plurality and ambiguity, the anxiety and uncertainty of interpretation finds illumination in the dark. 